\title{
PENGARUH METODE DRILL TERHADAP HASIL BELAJAR PESERTA DIDIK MATA PELAJARAN EKONOMI DI SMA
}

\author{
Oleh: Okta Sari ${ }^{1 *}$, Yasir Arafat ${ }^{2}$, Depi Pramika ${ }^{3^{*}}$ \\ oktasarianraya@gmail.com ${ }^{1 *}$, yasirarafat@univpgri-palembang.ac.id ${ }^{2}$, \\ depi.neynda0506@gmail.com ${ }^{3 *}$
}

(Program Studi Pendidikan Akuntansi, FKIP Universitas PGRI Palembang)

\begin{abstract}
Abstrak-Tujuan penelitian ini untuk mengetahui pengaruh metode drill terhadap hasil belajar peserta didik pada mata pelajaran ekonomi di SMA Negeri 2 Palembang. Metode penelitian yang digunakan metode Eksperimen dengan desain penelitian True Experimental Design. Hasil penelitian menunjukkan bahwa nilai rata-rata hasil post-test dari kedua kelas berbedah yaitu untuk kelas eksperimen sebesar 73,5 dengan kriteria "Aktif" sedangkan kelas kontrol 57,75 dengan kriteria "Cukup Aktif". Hipotesis menggunakan statistik non parametrik yaitu Uji Mann-Whitney diperoleh nilai $z_{\text {hitung }}>z_{\text {tabel }}$ yaitu 4,95 > 1,96 maka tolak $H_{o}$ dan Terima $H_{a}$. Maka dapat disimpulkan metode drill berpengaruh terhadap hasil belajar belajar peserta didik pada mata pelajaran ekonomi di SMA Negeri 2 Palembang.
\end{abstract}

Kata Kunci: Metode Drill, Hasil Belajar, Ekonomi

\begin{abstract}
The purpose of this study was to determine the effect of the drill method on student learning outcomes in economics subjects at SMA Negeri 2 Palembang. The research method used is the Experimental method with a True Experimental Design research design. The results showed that the average value of the post-test results from the two surgical classes, namely for the experimental class was 73.5 with the "Active" criteria, while the control class was 57.75 with the "Quite Active" criteria. The hypothesis uses non-parametric statistics, namely the MannWhitney test, the value of zcount > ztable is $4.95>1.96$, so reject Ho and accept Ha. So it can be concluded that the drill method has an effect on student learning outcomes in economic subjects at SMA Negeri 2 Palembang.
\end{abstract}

Keywords: Drill Method, Learning Outcomes, Economics

\section{PENDAHULUAN}

Menurut (Jubairiyani, 2020) "Pendidikan merupakan hal yang sangat penting bagi setiap orang, dengan adanya pendidikan mampu mencerdaskan kehidupan bangsa dan mengembangkan manusia yang beriman dan bertaqwa kepada Tuhan Yang Maha Esa, memiliki kemampuan dan keterampilan, kesehatan jasmani dan rohani, kepribadian yang mantap dan mandiri serta rasa tanggungjawab". 
Guru merupakan salah satu faktor yang mempunyai peran dan fungsi dalam dunia pendidikan. Guru adalah bagian terpenting dalam proses belajar mengajar, di jalur pendidikan formal, informal, atau nonformal. Oleh sebab itu, dalam setiap upaya peningkatan kualitas pendidikan di tanah air, guru tidak dapat dilepaskan dari berbagai hal yang berkaitan dengan eksistensi mereka.

Dalam dunia pendidikan tidak terlepas dari belajar dan hasil belajar. Menurut (Nunuk Suryani, 2012, hal. 34) "Belajar merupakan hal yang sangat penting bagi setiap orang, karena dengan belajar seseorang memahami dan menguasai sesuatu sehingga orang tersebut dapat meningkatkan kemampuannya. Belajar merupakan perkembangan hidup manusia yang dimulai sejak lahir dan berlangsung seumur hidup."

Menurut (Asep Jihad, 2019, hal. 1), "Belajar adalah kegiatan berproses dan merupakan unsur yang sangat fundamental dalam penyelenggaraan jenis dan jenjang pendidikan, hal ini berarti keberasilan pencapaian tujuan pendidikan sangat tergantung pada keberasilan proses belajar siswa di sekolah dan lingkungan sekitarnya."

Belajar adalah suatu proses yang dilakukan seseorang dengan mengamati, membaca, meniru, mencoba sesuatu, mendengar dan mengikuti arah tertentu. Sedangkan hasil belajar merupakan interaksi atau hubungan timbal balik antara peserta didik dengan pendidik dalam proses pembelajaran.

Proses

pembelajaran merupakan upaya untuk membantu perkembangan peserta didik, baik sebagai makhluk individu maupun sebagai makluk sosial. Melalui kegiatan dan proses pembelajaran, peserta didik dibekali dengan berbagai ilmu pengetahuan, dikembangkan nilai-nilai moralnya dan juga keterampilan yang di milikinya. Oleh karena itulah kegiatan dan proses pembelajaran merupakan salah satu faktor penting yang harus diperhatikan karena kegiatan ini merupakan proses yang betul-betul harus dikuasai oleh seorang pendidik yang erat kaitannya dengan tugas kesehariannya.

Proses pendidikan di sekolah merupakan upaya lembaga yang berfungsi membantu khususnya orang tua dalam memberikan pendidikan kepada anak-anak mereka. Sekolah memberikan pengetahuan, keterampilan dan sikap kepada anak didiknya secara lengkap sesuai dengan yang mereka butuhkan.

Pembelajaran merupakan proses yang rumit karena tidak sekedar menyerap informasi dari guru, tetapi juga melibatkan berbagai kegiatan dan tindakan yang harus dilakukan untuk mencapai hasil belajar yang baik. Salah satu metode penyampaian informasi yang sering 
di gunakan oleh guru adalah metode ceramah. Metode ceramah berbentuk penjelasan konsep, prinsip, dan fakta yang pada akhirnya ditutup dengan tanya jawab antara guru dan siswa.

Menurut (Kunandar, 2015, hal. 62), "Hasil belajar adalah kompetensi atau kemampuan tertentu baik kognitif, efektif maupun psikomotorik yang dicapai atau dikuasai peserta didik setelah mengikuti proses belajar mengajar." Sedangkan Menurut (Susanto, 2016, hal. 5), "Hasil belajar adalah perubahan-perubahan yang terjadi pada diri siswa, baik yang menyangkut aspek kognitif, afektif, dan psikomotor sebagai hasil dari kegiatan belajar."

Hasil belajar merupakan suatu proses timbal balik antara pendidik dengan peserta didik dalam proses pembelajaran, yang dapat diukur dengan hasil pencapaian belajar peserta didik. Hasil belajar siswa di SMA Negeri 2 Palembang masih rendah dikarenakan kurangnya minat dan kemauan siswa dalam belajar.

Salah satu faktor yang mempengaruhi hasil belajar adalah metode pembelajaran. Menurut (Ahmadi, 2017, hal. 73) "Metode pembelajaran merupakan salah satu komponen dalam pendidikan (pembelajaran). dengan metode yang tepat, pembelajaran akan berlangsung secara efektif dan sebaliknya jika penggunaan metode tidak tepat bisa berpengaruh negatif pada pembelajaran".
Menurut (Sani, 2016, hal. 58) Metode pembelajaran merupakan langkah operasional dari strategi pembelajaran yang dipilih untuk mencapai tujuan pembelajaran. Salah satunya adalah metode drill.

Metode latihan (drill) disebut juga metode training, yaitu suatu cara mengajar untuk menanamkan kebiasaan-kebiasaan tertentu, serta sebagai sarana untuk memelihara kebiasaan-kebiasaan yang baik. Selain itu metode ini digunkan untuk memperoleh suatu ketangkasan, ketepan, kesempatan, dan keterampilan. (Hamdayama, 2017, hal. 103-104)

Menurut (Majid, 2013, hal. 214), "drill secara denotatif merupakan tindakan untuk meningkatkan keterampilan dan kemahiran. Sebagai sebuah metode, drill adalah cara membelajarkan siswa untuk mengembangkan kemahiran dan keterampilan serta dapat mengembangkan sikap dan kebiasaan.

Pendapat yang sama dikemukakan oleh (Daryanto, 2017, hal. 122), "Metode latihan disebut juga metode training, yaitu suatu cara belajar untuk menanamkan kebiasaan-kebiasaan tertentu juga sebagai sarana untuk memelihara kebiasaan-kebiasaan yang baik. Selain itu, metode ini dapat digunakan untuk memperoleh suatu ketangkasan, ketepatan, kesempatan, dan keterampilan. 
Adapun Langkah-langkah metode drill Menurut (Roestiyah, 2012, hal. 127-128), sebagai berikut:

a. Gunakanlah latihan ini hanya untuk pelajaran atau tindakan yang dilakukan secara otomatis, ialah yang dilakukan siswa tanpa menggunakan pemikiran dan pertimbangan yang mendalam. Tetapi dapat dilakukan dengan cepat seperti gerak reflex saja, seperti: menghafal, menghitung, lari dan sebagainya.

b. Guru harus memilih latihan yang mempunyai arti luas ialah yang dapat menanamkan pengertian pemahaman akan makna dan tujuan latihan sebelum mereka melakukan. Latihan itu juga mampu menyandarkan siswa akan kegunaan bagi kehidupannya saat sekarang ataupun di masa yang akan mendatang. Juga dengan latihan itu siswa merasa perlunya untuk melengkapi pelajaran yang diterimanya.

c. Di dalam latihan pendahuluan instruktur harus lebih menekankan pada diagnosa, karena latihan permulaan itu kita belum bisa mengharapkan siswa dapat menghasilkan keterampilan yang sempurna. Pada latihan berikutnya guru perlu meneliti kesukaran atau hambatan yang timbul dan dialami siswa, sehingga dapat memilih/menentukan latihan mana yang perlu diperbaiki. Kemudian instruktur menunjukan kepada siswa response/tanggapan yang telah benar, dan memperbaiki response-response yang salah. Kalau perlu guru mengadakan varasi latihan dengan mengubah situasi dan kondisi latihan, sehigga timbul response yang berbeda untuk peningkatan dan penyempurnaan kecakapan atau keterampilannya.

d. Perlu mengutamakan ketepatan, agar siswa melakukan latihan secara tepat, kemudian diperhatikan kecepatan; agar siswa dapat melakukan kecepatan atau keterampilan menurut waktu yang telah ditentukan; juga perlu diperhatikan pula apakah responden siswa telah dilakukan dengan tepat dan cepat.

e. Guru memperhitungkan waktu/masa latihan yang singkat saja agar tidak meletihkan dan membosankan, tetapi sering dilakukan pada kesempatan lain. Masa latihan itu harus menyenakan dan menarik, bila perlu dengan mengubah situasi dan kondisi sehingga menimbulkan optimisme pada siswa dan memungkinkan rasa gembira itu bisa menghasilkan keterampilan yang baik.

f. Guru dan siswa perlu memikirkan dan mengutamakan proses-proses yang esensial/yang pokok atau inti; sehingga tidak tenggelam pada hal-hal yang rendah/tidak perlu kurang diperlukan. 
g. Instruktur perlu memperhatikan perbedaan individual siswa; sehingga kemampuan dan kebutuan siswa masing-masing tersaluran/dikembangkan. Maka dalam pelaksanaan latihan guru perlu mengawasi dan memperhatikan latihan perseorangan.

Berdasarkan informasi yang didapat dari guru mata pelajaran ekonomi diketahui pembelajaran dilkukan secara online/daring melalui aplikasi Google Classroom. Metode pembelajaran yang digunakan adalah Penugasan tanpa didampingi dan diketahui juga hasil belajar siswa dengan metode penugasan tanpa didampingi tersebut rata-rata nilai siswa tidak mencapai KKM. Rendahnya hasil belajar disebabkan karena pembelajaran ini kurang menarik sehingga membuat siswa jenuh saat belajar. Metode pembelajaran yang dilakukan hanya penugasan saja tanpa didampingi dan tidak ada metode lain. Selain itu materi tidak ada penjelasannya.

Melihat permasalahan maka metode drill terhadap hasil belajar dipandang relavan dengan masalah di atas dalam rangka untuk meminimalisir permasalahan tersebut. pemilihan metode drill ini untuk diterapkan dalam proses pembelajaran di SMA Negeri 2 Palembang. Dilandaskan agar peserta didik bisa menanamkan kebiasaankebiasaan baik sehingga diperoleh suatu ketangkasan, ketepatan, kesempatan, dan keterampilan.

Berdasarkan latar belakang maka peneliti tertarik untuk meneliti tentang judul "Pengaruh Metode Drill Terhadap Hasil Belajar Peserta Didik Pada Mata Pelajaran Ekonomi Di SMA Negeri 2 Palembang"

Berdasarkan rumusan masalah, maka tujuan dari penelitian ini adalah untuk mengetahui pengaruh metode drill terhadap hasil belajar peserta didik pada mata pelajaran ekonomi di SMA Negeri 2 Palembang.

Manfaat penelitian terbagi menjadi dua yaitu : 1) Manfaat Teoritis, Hasil penelitian ini diharapkan dapat bermanfaat bagi peneliti dapat menambah wawasan dan pengetahuan dalam proses peningkatan mutu pelajaran dan juga dapat menjadi bahan refrensi untuk penelitian lebih lanjut khususnya dalam bidang ilmu pendidikan ekonomi. 2) Manfaat Praktis: a) Bagi siswa, agar siswa lebih aktif dan kreatif sehingga memiliki kemampuan dalam belajar mandiri mengerjakan latihan soal-soal. b) Bagi guru, sebagai bahan masukan dalam melaksankan proses pembelajaran dengan menggunakan metode drill untuk meningkatkan hasil belajar siswa. c) Bagi sekolah, dapat meningkatkan kualitas proses pembelajaran lebih optimal karena metode yang diajarkan selama ini sudah cukup baik. 


\section{METODE PENELITIAN}

Metode penelitian merupakan proses kegiatan dalam bentuk pengumpulan data, analisis dan memberikan interpretasi yang terkait dengan tujuan penelitian. (Sugiyono, 2019, hal. 2). Metode yang digunakan dalam penelitian ini adalah metode eksperimen, pendekatan kuantitatif. Menurut (Sugiyono, 2019, hal. 127) metode ekperimen adalah metode penelitian kuantitatif yang digunakan untuk mengetahui pengaruh variabel independen (treatment/perlakukan) terhadap variabel dependen (hasil) dalam kondisi yang terkendalikan.

Dalam penelitian ini, desain penelitian True Experimental Design dengan bentuk Posttest-Only Control Design. Menurut (Sugiyono, 2019, hal. 132) ciri utama dari True Experimental adalah bahwa, sampel yang digunakan untuk eksperimen maupun sebagai kelompok kontrol diambil secara random dari populasi tertentu. Jadi cirinya adalah adanya kelompok kontrol dan sampel dipilih secara random. Dalam desain true experimental, karena kelompok diambil secara random dan bila datanya interval atau rasio, maka pengujian signifikansi pengaruh treatment menggunakan statistik parametris t-test related (untuk dual kelompok sampel berpasangan) dan analisis varian bila kelompoknya lebih dari dua.

Waktu penelitian yang digunakan kurang lebih 1 Bulan dimulai dari 19 Juli sampai dengan 5 Agustus 2021 di SMA Negeri 2 Palembang. Tempat penelitian dilakukan di SMA Negeri 2 Palembang yang beralamat di Jln. Puncak Sekuning No. 84, Lorok Pakjo, Kec. Ilir Barat 1, Kota Palembang, Sumatera Selatan 30137. Populasi adalah wilayah generalisasi yang terdiri atas: obyek/subyek yang mempunyai kuantitas dan karakteristik tertentu yang ditetapkan oleh peneliti untuk dipelajari dan kemudian ditarik kesimpulannya (Sugiyono, 2019, hal. 145). Yang menjadi populasi dalam penelitian ini adalah semua kelas XI IPS SMA Negeri 2 Palembang yang terdiri dari 4 kelas.

Tabel 1. Populasi Siswa Kelas XI SMA Negeri 2 Palembang

\begin{tabular}{|c|c|c|c|c|}
\hline No. & Kelas & Laki-laki & Perempuan & Jumlah siswa \\
\hline 1. & X1 IPS 1 & 24 & 16 & 40 \\
\hline 2. & X1 IPS 2 & 23 & 16 & 39 \\
\hline 3. & XI IPS 3 & 20 & 20 & 40 \\
\hline 4. & XI IPS 4 & 24 & 16 & 40 \\
\hline \multicolumn{2}{|c|}{ Jumlah } & 91 & 68 & 159 \\
\hline
\end{tabular}

Sumber: Tata usaha SMA Negeri 2 Palembang 
Sampel adalah bagian dari jumlah dan karakteristik yang dimiliki populasi (Sugiyono, 2019, hal. 146). Pada SMA Negeri 2 Palembang pembagian kelasnya tidak berdasarkan peringkat siswa, pembagian kelasnya secara acak sehingga kemampuan siswa di semua kelas sama atau homogen. Karena homogen maka penarikan sampel dilakukan secara acak (random) dengan teknik simple random sampling (sampel acak) yaitu pengundian.

Berhubung peneliti dalam melaksanakan pembelajaran menggunakan kelas yang ada, karena tidak memungkinkan untuk membentuk kelas baru, maka pengambilan sampel digunakan secara undian dari 4 kelas yang ada. Hasil undian yang keluar yaitu kelas XI IPS 3 dan XI IPS 4. Maka yang menjadi sampel dalam penelitian ini yaitu Kelas XI IPS 3 sebagai Kelas kontrol dan Kelas XI IPS 4 sebagai Kelas eksperimen.

Teknik Pengumpulan Data yang di gunakan pada penelitian ini :

1) Dokumentasi

Dokumentasi yaitu mencari data mengenai hal-hal atau variabel yang berupa catatan, transkip, buku, surat kabar, majalah, prasasti, notulen rapat, lengger, agenda, dan sebagainya (Arikunto, 2010, hal. 274).

2) observasi
Menurut Hadi (1986) dalam buku (Sugiyono, 2019, hal. 238) observasi merupakan suatu proses yang kompleks, suatu proses yang tersusun dari berbagai proses biologis dan psikhologis. Dua di antara yang terpenting adalah prosesproses pengamatan dan ingatan.

3) Tes

Tes merupakan himpunan pertanyaan yang harus dijawab, harus ditanggapi, atau tugas yang harus dilaksanakan oleh orang yang dites. Tes digunakan untuk mengukur sejauh mana seorang siswa telah mengusai pelajaran yang disampaikan terutama meliputi aspek pengetahuan dan keterampilan (Asep Jihad, 2019, hal. 67).

Hasil uji coba instrumen : 1) Uji Validitas Tes 2) Uji Reabilitas Instrumen Tes. Teknik Analisis data menggunakan statistik non parametrik bila data berdistribusi tidak normal: 1) Uji Normalitas Data, 2) Uji Homogenitas, 3) Uji U Mann Whitney.

\section{HASIL DAN PEMBAHASAN}

Uji normalitas data adalah pengujian untuk mengetahui kenormalan distribusi data. Untuk mengetahui apakah data yang kita miliki normal atau tidak, maka kita menggunakan uji statistik kolmogorov-smirnov. 
Tabel 2. Hasil Uji Normalitas

\begin{tabular}{|c|c|c|c|c|c|c|}
\hline \multicolumn{7}{|c|}{ Tests of Normality } \\
\hline & \multicolumn{3}{|c|}{ Kolmogorov-Smirnov $^{\mathrm{a}}$} & \multicolumn{3}{|c|}{ Shapiro-Wilk } \\
\hline & Statistic & Df & Sig. & Statistic & Df & Sig. \\
\hline XI IPS 3 &, 158 & 40 & ,013 & 954 & 40 & ,100 \\
\hline \multirow[t]{2}{*}{ XI IPS 4} & & & & & & \\
\hline & ,154 & 40 & ,018 & ,922 & 40 & ,009 \\
\hline
\end{tabular}

Sumber : Data Primer yang diolah SPSS For Windows ver.22

Berdasarkan tabel di atas dengan menggunakan uji Kolmogorov-Smirnov, didapat nilai signifikansi untuk kelas XI IPS 3 (kelas kontrol) sebesar 0,013 yang berarti lebih kecil dari 0,05 . Dan untuk kelas XI IPS 4 (kelas eksperimen) nilai signifikansinya sebesar 0,018 yang berarti lebih kecil dari 0,05. Berdasarkan hasil tersebut maka dapat disimpulkan bahwa data berdistribusi tidak normal. Menurut (Aridanu, Statistik Parametrik Penelitian Pendidikan, 2017, hal. 56) kriteria pengujian dengan menggunakan kolmogorov-dmirnov atau uji lilliefors yakni data dikatakan berdistribusi normal apabila.

a. Nilai signifikan atau nilai probalitas (signifikan) $>a=0,05$ maka data dinyatakan berdistribusi normal.

b. Nilai signifikan atau nilai probalitas (signifikan) $<a=0,05$ maka data dinyatakan tidak berdistribusi normal.

Setelah uji normalitas dilakukan, penelitian melakukan uji homogenitas yang mempunyai tujuan untuk mengetahui homogen tidaknya dalam suatu penelitian.

Tabel 3. Hasi Uji Homogenitas

Test of Homogeneity of Variances

Hasil Belajar

\begin{tabular}{|c|c|c|c|}
\hline Levene Statistic & df1 & df2 & Sig. \\
\hline 1,155 & 1 & 78 &, 286 \\
\hline
\end{tabular}

Sumber : Data Primer yang diolah SPSS For Windows ver.22

Berdasarkan tabel di atas dengan menggunakan uji test of homogeneity of variances, didapat nilai signifikansi sebesar 0,286 yang berarti lebih besar dari 0,05 .
Berdasarkan hasil tersebut maka dapat disimpulkan bahwa data homogen. Menurut Basrowi, dkk,2007:98-106 didalam buku (Aridanu, 2017, hal. 67) dikatakan 
memenuhi asumsi bahwa variansnya homogen dengan ketentuan sebagai berikut.

a. Jika probabilitas atau nilai signifikan $\geq 0,05$, maka varians sampel dinyatakan homogen.

b. Jika probabilitas atau nilai signifikan $\leq 0,05$, maka varians sampel dinyatakan tidak homogen.

Hasil uji normalitas diketahui data berdistribusi tidak normal, maka jenis statistik yang digunakan adalah non parametrik dengan menggunakan uji mann whitney.

Tabel 4. Uji Mann Whitney

Test Statistics $^{\mathrm{a}}$

\begin{tabular}{|c|c|}
\hline & Hasil Belajar \\
\hline Mann-Whitney U & 285,000 \\
\hline Wilcoxon W & 1105,000 \\
\hline Z & $-4,984$ \\
\hline Asymp. Sig. (2-tailed) &, 000 \\
\hline
\end{tabular}

a. Grouping Variable: KELAS

Sumber : Data Primer yang diolah SPSS For Windows ver. 22

Berdasarkan tabel di atas didapatkan nilai sig. (2-tailed) sebesar 0,000 yang berarti lebih kecil dari 0,05. Maka dapat disimpulkan bahwa hipotesis diterima yang artinya ada perbedaan hasil belajar antara kelas kontrol dan kelas eksperimen. Karena ada ada perbedaan yang signifikan maka dapat dikatakan bahwa "Ada Pengaruh Metode Drill Terhadap Hasil Belajar Peserta Didik Pada Mata Pelajaran Ekonomi Di SMA Negeri 2 Palembang."

Dalam penelitian ini, peneliti memiliki tujuan untuk mengetahui apakah ada pengaruh metode driil terhadap hasil belajar peserta didik pada mata pelajaran ekonomi di SMA Negeri 2 Palembang. Peneliti menggunakan metode drill pada mata pelajaran ekonomi materi tentang pendapatan nasional, dimana kelas eksperimen yaitu kelas XI IPS 4 berjumlah 40 siswa Dan dari hasil yang diperoleh pada saat penelitian proses pembelajaran dengan menggunakan metode drill siswa lebih aktif dan semangat dalam belajar ekonomi materi pendapatan nasional.

Sedangkan untuk kelas kontrol kelas XI IPS 3 berjumlah 40 siswa, dalam penelitian ini peneliti hanya menggunakan metode ceramah pada saat belajar banyak siswa yang merasa bosan dan jenuh untuk mendengarkan materi yang disampaikan oleh peneliti. Hal ini dapat dilihat dari hasil penelitian rata-rata hasil belajar yang di dapat dari hasil tes siswa untuk kelas 
ekperimen nilai rata-rata sebesar 73,5 dengan nilai tertinggi siswa sebesar 90 dan nilai terendah siswa sebesar 50. Sedangkan untuk kelas kontrol nilai rata-rata sebesar 57,75 dengan nilai tertinggi siswa sebesar 75 dan nilai terendah siswa sebesar 35 .

Berdasarkan hasil observasi yang dilakukan di kelas eksperimen dan di kelas kontrol terdapat perbedaan, kelas ekseperimen lebih aktif dibandingkan dengan kelas kontrol. Hal ini dapat dilihat dari hasil rata-rata observasi untuk dua pertemuan di kelas eksperimen dan kelas kontol, untuk kelas eksperimen yang menggunakan metode drill mengalami peningkatan dalam segi keaktifan belajar siswa di setiap pertemuannya, dapat dilihat dari nilai rata-rata pada pertemuan pertama sebesar 67,5 dengan nilai tertinggi siswa sebesar 83 dan nilai terendah siswa sebesar 58 sedangkan untuk pertemuan kedua nilai rata-rata sebesar 82,083 dengan nilai tertinggi siswa sebesar 92 dan nilai terendah siswa sebesar 75 . sehingga didapat nilai keseluruhan rata-rata untuk pertemuan pertama dan kedua sebesar 74,7375 dengan "kriteria aktif".

Sedangkan untuk kelas kontrol yang tidak menggunakan metode drill tidak mengalami peningkatan keaktifan belajar siswa disetiap pertemuannya, hal ini dapat dilihat dari nilai rata-rata pada pertemuan pertama sebesar 70,2 dengan nilai tertinggi siswa sebesar 92 dan nilai terendah sebesar 58 sedangkan nilai rata-rata pertemuan kedua sebesar 70,825 dengan nilai terbesar siswa 92 dan nilai terendah sebesar 58. Sehingga didapat nilai rata-rata keseluruhan pertemuan pertama dan kedua sebesar 70,525 dengan "kriteria cukup aktif".

Hasil dari uji normalitas data pada hasil tes untuk kelas kontrol didapat $\mathrm{x}^{2}$ hitung sebesar 58,63 dan $\mathrm{x}_{\text {tabel }}^{2}$ sebesar 11,070 dengan taraf nyata $5 \%$ dengan kriteria pengujian jika $\quad x^{2}$ hitung $\geq x_{\text {tabel }}^{2}$ artinya berdistribusi data tidak normal dan jika $\mathrm{x}^{2}$ hitung $\leq \mathrm{x}^{2}$ hitung artinya data berdistribusi normal. Berdasarkan hasil perhitungan $\mathrm{x}^{2}$ hitung $\geq \mathrm{x}_{\text {tabel }}^{2}$ yaitu 58,63 > 11,070 maka data berdistribusi tidak normal.

Hasil uji normalitas data pada hasil tes untuk kelas eksperimen didapat $\mathrm{x}^{2}$ hitung sebesar 75,98 dan $\mathrm{x}^{2}$ tabel sebesar 11,070 dengan taraf nyata $5 \%$ dengan kriteria pengujian jika $\mathrm{x}_{\text {hitung }}^{2} \geq \mathrm{x}_{\text {tabel }}^{2}$ artinya berdistribusi data tidak normal dan jika $\mathrm{x}^{2}{ }_{\text {hitung }} \leq \mathrm{x}^{2}{ }_{\text {hitung }}$ artinya data berdistribusi normal. Berdasarkan hasil perhitungan $\mathrm{x}_{\text {hitung }}^{2} \geq \mathrm{x}_{\text {tabel }}^{2}$ yaitu $75,98>11,070$ maka data berdistribusi tidak normal.

Berdasarkan hasil uji normalitas dari kedua data di atas menunjukkan bahwa data berdistribusi tidak normal. Maka menggunakan uji statistik non parametrik dengan menggunkan pengujian hipotesis uji mann whitney dengan sampel besar. 
Hasil hipotesis yang menggunakan Uji Mann Whitney dengan sampel besar didapat $z_{\text {hitung }}$ sebesar 4,95 dan $\mathrm{Z}_{\text {tabel }}$ sebesar 1,96 pada tingkat kesalahan 5\% dengan kriteria penguji jika $Z_{\text {hitung }}>Z_{\text {tabel }}$ maka tolak $\mathrm{H}_{0}$ dan terima $\mathrm{H}_{\mathrm{a}}$, Sebaliknya jika $\mathrm{z}_{\text {hitung }}<\mathrm{z}_{\text {tabel }}$ maka terima $\mathrm{H}_{0}$ dan tolak $\mathrm{H}_{\mathrm{a}}$. Berdasarkan hasil perhitungan $z_{\text {hitung }}>z_{\text {tabel }}$ yaitu 4,95> 1,96 maka tolak $\mathrm{H}_{0}$ dan terima $\mathrm{H}_{\mathrm{a}}$. Jika disimpulkan metode drill berpengaruh signifikan terhadap hasil belajar peserta didik pada mata pelajaran ekonomi di SMA Negeri 2 Palembang.

Berdasarkan hasil peneliti di atas diketahui ada pengaruh metode drill terhadap hasil belajar. Hasil sesuai dengan pendapat Jumanta Hamdayama (2017) pendapatnya "metode latihan (drill) disebut juga metode training, yaitu suatu cara mengajar untuk menanamkan kebiasaan-kebiasaan tertentu, serta sebagai sarana untuk memelihara kebiasaan-kebiasaan yang baik."

Hasil ini sejalan juga dengan hasil penelitian Arif Ariyanto, Witarsa dan Maria Ulfah, (2019) dengan judul Penerapan Metode Drill Pada Mata Pelajaran Ekonomi Pada Siswa Kelas XI SMA Santun Untan. Dalam penelitian ini peningkatan hasil belajar siswa dapat dilihat dari data rata-rata presentase hasil belajar siswa yang tuntas sebelum menerapkan metode drill sebesar $65.67 \%$ menjadi $77.13 \%$ sesudah menerapkan metode drill.
Peningkatan telah memenuhi kriteria keberhasilan sebesar $\leq 75 \%$ sehingga penelitian ini dapat dikatakan berhasil.

\section{KESIMPULAN}

Dari keseluruhan rangkai hasil penelitian yang telah dilakukan maka dapat disimpulkan bahwa Ada pengaruh yang signifikan antara Metode Drill Terhadap Hasil Belajar Peserta Didik Pada Mata Pelajaran Ekonomi Di SMA Negeri 2 Palembang.

Berdasarkan hasil data postest terlihat bahwa nilai rata-rata postest pada kelas eksperimen berbedah dengan kelas kontrol. Nilai rata-rata postest di kelas eksperimen yaitu sebasar 73,5 sedangkan nilai rata-rata postest di kelas kontrol yaitu sebesar 57,75. Berdasarkan hasil uji hipotesis Uji Mann-Whitney $\mathrm{z}_{\text {hitung }}>\mathrm{z}_{\text {tabel }}$ yaitu 4,95 > 1,96 maka tolak $\mathrm{H}_{0}$ dan terima $\mathrm{H}_{\mathrm{a}}$. Sehingga terdapat perbedaan yang signifikan dari hasil belajar siswa pada mata pelajaran ekonomi antara kelas kontrol dan kelas eksperimen. Jika disimpulkan metode drill berpengaruh signifikan terhadap hasil belajar peserta didik pada mata pelajaran ekonomi di SMA Negeri 2 Palembang.

Usaha untuk meningkatkan motivasi serta hasil belajar siswa dalam kegiatan pembelajaran, maka peneliti mencoba untuk memberikan beberapa saran-saran sebagai berikut: 1) Bagi siswa, hendaknya lebih giat lagi belajar dan memperbanyak 
informasi tentang ilmu pengetahuan dengan membaca buku dan memperbanyak mengerjakan latihanlatihan dalam bentuk soal agar siswa memiliki kemampuan serta keterampilan saat mengikuti proses pembelajaran. 2) Bagi guru, hendaknya memotivasi siswa agar siswa mampu menggali potensi dalam dirinya supaya dapat memecahkan permasalahan yang dihadapinya dalam proses pembelajaran. Salah satu yang dapat dilakukan guru yaitu lebih sering memberikan latihan dan tugas serta menggunakan metode mengajar yang tepat agar dapat meningkatkan hasil belajar siswa. 3) Bagi sekolah, metode drill di sekolah diharapkan mampu diterapkan pada mata pelajaran lain selain mata pelajaran ekonomi.

\section{UCAPAN TERIMA KASIH}

Penulis menyampaikan rasa terima kasih banyak kepada seluruh pihak yang membantu atas kelancaran penelitian terutama Bapak Dr. H. Bukman Lian, M.M., M.Si selaku Rektor Universitas PGRI Palembang, Ibu Dr. Dessy Wardiah, M.Pd selaku Dekan FKIP Universitas PGRI Palembang, Ibu Neta Dian Lestari,S.Pd., M.M selaku Ketua Program Studi Pendidikan Akuntansi, Bapak Dr. Yasir Arafat, S.E., M.M selaku Dosen Pembimbing Utama, Ibu Depi PramikaS.Pd., M.Si selaku Dosen Pembimbing Pendamping, SMA
Negeri 2 Palembang yang telah memberikan izin kepada saya untuk melakukan penelitian dan Dosendosen Prodi Pendidikan Akuntansi terima kasih atas ilmu yang telah Bapak dan Ibu dosen berikan kepada saya. Penulis memohon maaf apabila terdapat kekurangan ataupun kesalahan dalam proses penyusunan artikel ini. Semoga artikel ini dapat memberikan manfaat dan ilmu baru bagi para pembaca dan memberikan kontribusi yang baik bagi perkembangan pengetahuan.

\section{DAFTAR PUSTAKA}

Ahmadi, R. (2017). Pengantar Pendidikan Asas \& Filsafat Pendidikan. Maguwoharjo, Depok, Sleman, Yogyakarta: AR-RUZZ MEDIA

Aridanu, N. K. (2017). Statistik Parametrik Penelitian Pendidikan. $\quad$ Palembang: Noerfikri Offset.

Arif Ariyanto, W. M. (2019). Penerapan Metode Drill Pada Mata Pelajaran Ekonomi Pada Siswa Kelas XI SMA Santun Untan. Jurnal Pendidikan Dan Pembelajaran Khatulistiwa, 6.

Arikunto, S. (2010). Prosedur Penelitian Suatu Pendekatan Pratik. Jakarta: PT Rineka Cipta.

Asep Jihad, A. H. (2019). Evaluasi Pembelajaran. Baturetno, Banguntapan, Bantul, Yogyakarta: Multi Pressindo.

$\begin{array}{ccc}\text { Daryanto, } & \text { S. } & \text { K. (2017). } \\ \text { Pembelajaran } & \text { Abad } & 21 . \\ \text { Yogyakarta: Gava Media. }\end{array}$


Hamdayama, J. (2017). Metodologi Pengajaran. Jakarta: PT Bumi Aksara.

Jubairiyani, M. U. (2020). Penerapan Metode Drill Terhadap Hasil Belajar Dasar Akuntansi Kelas $X$ Di SMK Panca Bhakti Sungai Raya. Jurnal Pendidikan Dan Pembelajaran Khatulistiwa, 1.

Kunandar. (2015). Penilaian Autentik (Penilaian Hasil Belajar Peserta Didik Berdasarkan Kurikulum 2013). Jakarta: PT RajaGrafindo Persada.

Majid, A. (2013). Strategi Pembelajaran. Bandung: PT Remaja Rosdakarya.

Nunuk Suryani, A. S. (2018). Media Pembelajaran Inovatif dan Pengembangannya. Bandung: PT Remaja Rosdakarya.

Roestiyah. (2012). Strategi Belajar Mengajar. Jakarta: Pt Rineka Cipta.

Sani, R. A. (2016). Inovasi Pembelajaran. Jakarta: PT Bumi Aksara.

Sugiyono. (2019). Metode Penelitian Pendidikan (Kuantitatif, Kualitatif, Kombinasi, $R \& D$ dan Penelitian Pendidikan). Bandung: Alfabeta.

Susanto, A. (2016). Teori Belajar \& Pembelajaran di sekolah Dasar. Jakarta: Prenada Media Group. 